\title{
IMPROVING STUDENTS' READING COMPREHENSION ACHIEVEMENT THROUGH THE CONCEPT ATTAINMENT MODEL
}

\author{
Nova Jayanti Harahap \\ novazhrp@gmail.com \\ Dosen Sekolah Tinggi Ilmu Ekonomi (STIE) Labuhan Batu, Indonesia
}

\begin{abstract}
ABSTRAK
This study aims at improving students' achievement in reading comprehension applying The Concept Attainment Model by conducting classroom action research. The subjects of this research the first semester students Majoring in Economics from Yayasan Universitas Labuhan Batu Rantauprapat. The number of the students was 20 students. There were two kinds of data collected during the study, quantitative and qualitative data. The instrument for collecting the quantitative data was objective test of reading comprehension, while the instruments for qualitative data were gathered through observation sheet, diary notes and check list. Based on the data analysis, the mean of the students score in pre-test 51 , in cycle I was 61.75, and in cycle II was 80.50. The conclusion is that The Students Concept Attainment Model can improve the students' achievement in reading comprehension.
\end{abstract}

Keywords: Descriptive Text, Reading Comprehension, The Concept Attaainment Model,

\section{INTRODUCTION}

English is the first foreign language taught in schools in Indonesia. It is an international language, which is used by many people all over the world to communicate among nations either in spoken or written form. Realizing that English is an international language that is why English used in a global setting language to be well mastered by many people. English is a very highly recommended due to the strong position of English world, the Indonesian Department of Education and Culture has put a special role in the teaching of English. English as a foreign language is taught stating form the Elementary School up to the university level.

In the teaching of a language, the four language skills namely listening, speaking, reading, and writing should be well taught and mastered by the students.

Since English is a new subject for most University, the lecturers have to make them interested in studying. Interest is an important factor to make them pay attention to the subject. The aim of teaching English in the University is to motivate them to be ready and have self confidence in learning English at higher levels of education.

Reading is the process of looking at a series of written symbols and getting meaning from them. When we read, we use our eyes to receive written symbols (letters, punctuation marks and spaces) and we use our brain to convert them into words, sentences and paragraphs that communicate something to us. Reading can be silent (in our head) or aloud ( so that 
peopple can hear). Reading is a receptive skill thought it we receive information. But the complex process of reading also requires the skill of speaking, so that we can pronounce the words that we read. In this sense, reading is also a productive skill in that we are both receiving information and transmitting it (even if only to ourselves).

Based on the writer's interview and observation at the first semester students Majoring in Economics from Yayasan Universitas Labuhan Batu Rantauprapat, most of the students got frustrated and lost their interesting in reading. The main problem was the students got difficulty in understanding a long list of words, because a teacher taught by asking the students to open the dictionary and the lecturers technique used in teaching English was not get interesting. It made students lazy learn English. For example, when they were bored with the class, they will open the Mobile Phone during the class and ignore the lesson given by the teacher. Therefore, the lecturers need to choose media that are best for students.

A research conducted by Panjaitan, Evalina (2010) shows that the students reading achievement can be improved through Anagram. Utatri, Ayu (2011) reveals that the students' reading can be improved through Memory Strategy. Based on the two researchers, the writer was sure to conduct the Concept Attainment Model to improve students' reading and vocabulary because the students' reading achievement can be better through some Strategy and the Concept Attainment Model is one of the model. Hopefully, this model can be successful as like anagram and memory strategy.

By applying the Concept Attainment Model, the writer should do something to help their students to improve their reading achievement. The writer wanted to apply the Concept Attainment Model as an alternative for teaching names of objects. The students were given something new and different from what they usually get in class. They were not only as the object of the teaching learning process but as also the participants. In other words, the writer made the students active instead of being silent. Through this study, the writer wanted to investigate a new teaching technique in order to increase the quality of English teaching learning process in University.

According to Martomidjojo (2009) the Concept Attainment can help students at all age levels in the understanding the concepts and hypothesis testing exercise. Sapra (2011:505) concludes in her research paper that the Concept Attainment Model focuses on meaning and understanding of the concept and to help the students internalize the scientific concepts rather than foster mere memorization. The model aims at acquistion of concepts which are flexible and have broader applicability. Ahmed et al (2012: 223) states the results showed that all the students including low achievers and high achievers, who were taught through the Concept Attainment Model performed significantly better than their counterparts taught through traditional method. Study results proved that the Concept Attainment Model emerged as effective instructional strategy in teaching of English.

From the results above, it can be summarized that the Concept Attainment Model is one of alternative and effective model to be applied to increase the students' reading. The students will get many words and enjoy while they were study the reading and also will motivate and encourage the students in learning. The other reason why the writer chooses the media for teaching reading is it can train the students in memorizing the words. 


\subsection{The Problem of Study}

"Does the use of Concept Attainment Model Improve the Students' Reading Achievement?"

\subsection{The Objective of the Study}

Teaching reading is a very important task in teaching a language, especially English. By using a good strategy to understand new vocabulary used in textbooks, students will find words easier to remember and will become more motivated in class so that they can improve their reading. There are many models to teach reading. One of the interesting and enjoyable teach reading is the Concept Attainment Model. Thus, the objective of this study is to find out whether the students' reading achievement will improve if they are taught by using the Concept Attainment Model.

\section{THEORETICAL REVIEW}

\subsection{The Concept Attainment}

The Concept Attainment Model was originally designed Edgen (1979) and is based on the research efforts Bruner et al. The two Information Processing Models are the general inductive and general deductive models. And inductive model designed to teach the Concept Attainment Model. Although it is similar to the general inductive model in the type of reasoning used, it is specifically designed to teach only one form of content, concepts. An understanding of concept learning in general is helpful to an understanding of the Concept Attainment Model.

The Concept Attainment is a good model in teaching reading. Learning Concept Attainment sharpen thinking skills base. The concept of learning model Attainment inherent teaching students to think, because in the Concept Attainment Model learning model there are several steps that must be passed, as concept formation by considering its various attributes.

By Using Concept Attainment Model begins with giving examples of the application of the concept to be taught, then by observing examples and lowering the definition of these concepts. The most important thing that must be considered by a teacher in the use of this learning model is the selection of an appropriate example for the concepts being taught, the examples of things that are familiar to the student. In principle, Concept Attainment Model of learning is a teaching strategy that uses the data to teach concepts to students, where teachers start teaching by presenting data or examples, then the teacher asked the students to observe the data or examples. On the basis of these observations will form abstraction. Attainment concept learning model can help students at all age levels in the understanding of the concepts and hypothesis testing exercise. 
According to Talkmitt (2008) The procedure of Concept Attainment Model are: (1) Give the students some examples of mammals, (2) During the strategy, ask for additional "yes" examples to verify that students are getting the concept, (3) Once most students seem to have the concept, ask for critical attributes that describe the concept, (4) List the critical attributes on the board, (5) Look at the critical attributes and derive a rule or a name for the concept, and (6) Have students discuss their thinking processes throughout the strategy.

According to Joyce (1980), the Concept Attainment Model is important because: (1) the purpose and emphasis of these two forms of categorizing behavior are different, (2) the steps of thinking processes are not the same, and (3) the two mental processes require different teaching processes.

The Concept Attainment Model is an indirect instructional strategy that uses a structured inquiry process. It is based on the work of Jerome Bruner. In Concept Attainment Model, students figure out the attributes of a group or category that has already been formed by the teacher. To do so, students compare and contrast examples that contain the attributes of the concept with examples that do not contain those attributes. They then separate them into two groups. The Concept Attainment Model, then, is the search for and identification of attributes that can be used to distinguish examples of a given group or category from nonexamples.

The Concept Attainment Model can best be described as an adapted language scheme which will unfold, rebuild and reconstruct cognitive structures in the mind of the learner. The strategy focuses on meaning and understanding of the concept. The students develops' thinking' skills and reasoning abilities as they examine concepts from expository texts. The objective of the model is help the students internalize the scientific concept rather than foster mere understanding. The attainment of scientific concepts which are formed and evolved during the learning process rather than presented ready made to the child.

The Concept attainment is designed to clarify ideas and to introduce aspects of content. It engages students into formulating a concept through the use of illustrations, word cards or specimens called examples. Students who catch onto the idea before others are able to resolve the concept and then are invited to suggest their own examples, while other students are still trying to form the concept. For this reason, concept attainment is well suited to classroom use because all thinking abilities can be challenged throughout the activity. With experience, children become skilled at identifying relationships in the word cards or specimens. With carefully chosen examples, it is possible to use concept attainment to teach almost any concept in all subjects.

The concept attainment model is clearly has many advantages in teaching learning. The advantages are (1) helps to making connections between what students know and what they will be learning (2) learn how to examine a concept from a number of perspectives (3) learn how to sort out relevant information (4) extends their knowledge of a concept by 
classifying more than one example of that concept (5) students go beyond merely associating a key term with a definition concept is learned more thoroughly and retention is improved.

\subsection{Analyzing Concept' Critical Attributes}

It is the critical attributes of a concept that make it possible for people to understand it and communicate about it with one another. Because a concept is an abstraction of objects, experiences or ideas that have shared critical attributes. This abstracting process, as explained earlier, is the basis of concept-attainment instruction. When they use this model, teacher present examples and non- examples of the concept and guide students in discriminating the critical attributes contained in the positive examplars and missing from the negative ones. Students then coalesce these attributes into an hypothesis of the concept. For this to occur successfully in the clasroom, teachers, themselves, must analyze each concept they intend to teach and must discriminate the critical attributes.

\section{Model}

Model of teaching can be defined as instructional design which describes the process of specifying and producing particular environmental situations which cause the students to interact in such a way that a specific change occurs in their behavior.

\section{Strategy}

Strategy is the plan or program that is extensively used to ensure that a certain message or lesson is passed from the teacher to the students. These plans use various means, either theoretical or practical.

To use the explanation above, the teacher first identifies the concept by name. In this case, the concept is a key topic in the study of U.S. Goverment, one that students need to understand as part of that study, and one that will be vital to them when they become adult, politically-participating citizens. The teacher begins using the topic itself as the concept name, than states the concept as a rule. This rule is an operational statement and explains the mental and/or physical actions that bring the concept into existence. The teacher also specifies the critical attributes of the concept, again the mental and physical actions necessary to concept presence, but this time stated individually in list form.

Teacher can carry out concept- analysis steps in any order, indentifing the concept name, rule or critical attributes first, second or last. As they work to develop and integrate these three components, they typically find that they arrive at a succint concept name, a complete rule statement and all critical attributes of the concept presented individually in alist. Teachers also find it helpful to "try out" their concept names, rules and critical atributtes with colleagues who teach in the same subject area and in this way, make sure that they have 
a comprehensive guide for designing the positive and negative exemplars that students will use to derive the concept.

\subsection{Reading}

Reading is a process of drawing meaning or grasping information from a written text and forming interpretation of that information (Grabe \& Stoller, 2002). When someone read a text, he or she expects an understanding to construct meaning. This understanding is called comprehension. Comprehending is a process through which a reader interacts with a text to construct meaning (Rice, 2009). A reader can derive meaning from a text by connecting his or her background or prior knowledge including knowledge of language and experience to the words he or she reads.

Reading text is not a simple process. Whenever someone read a text, he or she decodes the words in order to comprehend meanings. Of course, a reader is required to have reading skills or techniques to build comprehension. A reader also needs good prior knowledge in order to be able to predict and connect ideas lying in the text. These aspects comprehend written texts.

\subsection{Teaching Reading by Using the Concept Attainment Model}

The word concept refers not only to the object itself, but also to those attributes that make up's nation of the object. According toBruner quoted by Joyce (1996) states that when one sees an object that it is red, shiny and roundish and makes the inference that it is an apple, one is then enabled to infer further that "if it is an apple, it is also edible, juicy, will rot if left unrefrigerated. The working definition of a concept is the network or inferences that are or may be set into play by an act of categorization. The Concept Attainment Model inspires students to use critical thinking strategies to find critical attributes of a given concept. It seem like a game to students, but it actually requires higher level thinking skills.

The Concept Attainment Model use pictures, words, and/ or real objects to present the concept attainment strategy. Sequence the items in the order provided. Always start with a "yes" example. Follow with a "no" example. The addition examples should be given in random order. Do avoid giving too many "no" examples at one time. They are given to help clarify what the "yes" examples have in common.

Almost students felt difficult in reading because it is very hard for them to understand a long list of words. Thus, it is very important to choose learning strategy which can make them more enjoyable and more comfortable in the process of learning English.

The Concept Attainment is a good model in teaching reading. Learning Concept Attainment sharpen thinking skills base. The concept of learning model Attainment inherent teaching students to think, because in the Concept Attainment Model learning model there are several steps that must be passed, as concept formation by considering its various attributes. 
By Using Concept Attainment Model begins with giving examples of the application of the concept to be taught, then by observing examples and lowering the definition of these concepts. The most important thing that must be considered by a teacher in the use of this learning model is the selection of an appropriate example for the concepts being taught, the examples of things that are familiar to the student. In principle, Concept Attainment Model of learning is a teaching strategy that uses the data to teach concepts to students, where teachers start teaching by presenting data or examples, then the teacher asked the students to observe the data or examples. On the basis of these observations will form abstraction. Attainment concept learning model can help students at all age levels in the understanding of the concepts and hypothesis testing exercise.

According to Bruner, Goodnow \& Austin quoted by Martomidjojo (2009) states concept of learning is to find and list Attainment attributes that can be used to set examples (exemplars) rather than examples (non-exemplars) from various categories. While the establishment of the concept (concept formation), constitute the basis of inductive learning model. Learning Concept Attainment requires a fundamental decision to categoriescategories that will be constructed, requiring a student to be able to describe an attribute of a category that is ready to be formed in the brains of students through a compare and contrast examples (called exemplars) that it contains characteristics (attributes) of a concept with examples that do not contain attributes.

To conduct the learning of the Concept Attainment Model, 10 pair of students are needed and if the concept is more and more complex, of course, take a lot of pair of students. Attainment concept learning process starts with a question addressed to the students to examine carefully a sentence and the students give serious attention to the words that have been underlined. Then a teacher instructed the students to compare and contrast the function of exemplar positive and negative exemplar. Exemplar positive for something that is common work activities performed by the students in make sentences. Negative Exemplar not does different work.

Learning the Concept Attainment Model many involving mental operations students. In this case, the scientific model is needed to identify students' mental operations, especially for the achievement of the concept in a short time, including behavior analysis, observations, and ask must be done as a learning task. Analysis of behavior based on mental operation test students. Students are instructed to make notes about what they believe about exemplar already has. Then, the teacher gives some exemplar set and asked them if they still have the same idea. If not, the teacher asked what they are thinking. The teacher continues to present exemplar-exemplar that most students have an idea that they think will withstand the rigor of his research. At that time, the teacher asked one student to combine the idea of his friends and his friends how to incorporate his ideas.

\section{RESEARCH METHODE}


This research was designed as Classroom Action Research (CAR). Action research is a process in which participants examine their own educational practice systematically, focuses on individual or small group professional practice. According to Wallace (1998:16), action research including collecting and analysis of data relating to some aspect of lecturer's professional practice. After conducting the investigation of the students' problem in reading comprehension, the action can be applied.

\section{DATA ANALYSIS, FINDINGS AND DISCUSSIONS}

The subject of this study is the first semester students Majoring in Economics from Yayasan Universitas Labuhan Batu Rantauprapat, they are consisted of 20 students. The reason for choosing this class was because the writer found that the students had some problems in reading comprehension. In this research, there were two kinds of data will be used to know and measure the ability of the students in reading, those are the quantitative and qualitative data.

Multiple choice: this form of test would be used to conduct the quantitative data. The test that would be used a multiple choice test was a reading text. The purpose of this test was to measure the student's ability in comprehend a text and to construct an idea and the test will be arranged by the writer herself.

The qualitative data is used to describe the situation during teaching process. The qualitative data will be collected by using:

1) Observation Sheet: focused on the situation of teaching learning process, students' activities and behaviors, and students' ability by using focus group discussion method.

2) Diary notes: diary notes refer to transcribed notes or the written account derived from data collected during observations and interviews.

3) Check list: check list is the list, which was the correspondence only put check $(\sqrt{ })$ in the suitable column.

\subsection{Data Analysis}

This study was quantitative and qualitative data. The qualitative data were used to describe the situation during the teaching process and the quantitative data was used to analyze the score of the students. The qualitative data was analyzed from the observation sheet, diary notes and check list and the quantitative data was analyzed by computing the score of reading comprehension test.

The data deals with qualitative and quantitative data. The qualitative data were deals from observation sheet, diary notes and check list $(\sqrt{ })$, while the quantitative data were taken from the reading test during conducted research in six meetings. The reading test was given 
three times, the pre-test and two tests after each cycle. The result of the test was shown in the table below:

Table 1.

The Mean Score Students' Score of Pre-Test, Test Cycle I and Test Cycle II

\begin{tabular}{|l|l|l|}
\hline Test & Total score & Mean \\
\hline Pre-Test & 1020 & 51 \\
\hline Test Cycle I & 1235 & 61.75 \\
\hline Test Cycle II & 1610 & 80.50 \\
\hline
\end{tabular}

The data analysis revealed that there is an improvement of the students' score in reading comprehension, taught by using The Concept Attainment Model. In the pre-test, the number of students was 20 and the total score of the students was 1020, so the mean was 51 .

In the first treatment (Cycle I), the number of students was 20 and the total score of the students was 1235 , so the mean was 61.75 . The mean of the students' total score was below the minimum score standard/KKM (70). There were some cases why the students' mean were below the minimum score standard 70. In ycle I, the teaching material was not explained clearly and systematically so the enthusiasm of the students were still low because they were still confused to the apllication of the Concept Attainment Model on their reading comprehension, these whole cases were found on observation sheet, diary notes and check list $(\sqrt{ })$. So, there writer decided to conduct the cycle II to improve their understanding.

In the cycle II, the number of the students was 20 and the total score of the students was 1610 , so the mean was 80.50 . The students mean had improve above the minimum score standard and the whole students' score had above the minimm score standard (70) too. In this cycle, the weakness of the researcher in cycle I had reflected and as resulting the score and mean of the students had improved above standard (KKM). There were some efforts done to improve the students score and mean. The first, teaching material was taught well. The steps of the Concept attainment Model were followed more systematically.

The steps one is class presentation. The writer introduces the material to be learned, and the students were more active. In this way, students realized that they must pay attention during the class presentation because it helped them to do the quizzes well. The students listened to the teacher explanation seriously, they looked comfort and enjoy in the following the lesson process.

The step two is teams works. Function of the group is setting up so that, they can do the quiz as well. Students are assigned to four or five member learning teams to practices. After the teacher explains the material, each member of the group studied and discussed. Each team represents a cross section of the class, made up high, average, and low-achieving students. 
The students were easier to understand the material, because they understand what the story about and they had more information about the topics.

Table 2.

The Percentage of Students' Reading Competence

\begin{tabular}{|l|l|l|l|}
\hline Grade & Pre-Test & Cycle I Test & Cycle II Test \\
\hline $\begin{array}{l}\text { A } \\
(90-100)\end{array}$ & $0 \%$ & $0 \%$ & $\begin{array}{l}25 \% \\
(5 \text { students })\end{array}$ \\
\hline $\begin{array}{l}\text { B } \\
(80-89)\end{array}$ & $0 \%$ & $0 \%$ & $\begin{array}{l}30 \%(6 \\
\text { students })\end{array}$ \\
\hline $\begin{array}{l}\text { C } \\
(70-79)\end{array}$ & $0 \%$ & $20 \%$ & $25 \%$ \\
\hline D & & $(5$ students $)$ \\
$(60-69)$ & $10 \%$ & $50 \%$ & $20 \%$ \\
\hline E & $(2$ students $)$ & $(10$ students $)$ & students $)$ \\
$($ below 60$)$ & $90 \%$ & $30 \%$ & $0 \%$ \\
\hline
\end{tabular}

Based on the table above, it was found that the percentage of students' achievement level in grade A improved from cycle I to cycle II. There were some efforts that done by the writer, so the students got good improvement in grade A. The first is the teaching material was taught clearly and systematically, the students listen to the lecturer's explanation attentively so they understand the writer' explanation well. The second is giving the extrinsic motivation, because they wanted to get a reward, so they always focus and spirit to do their quiz. The third is making the class situation was more comfortable and enjoyable by making a jokes and quiz, so they felt relax in following the lesson process. According to the researcher notes, most of the students felt enjoyable in following the lesson because the writer' explanation is easy to understand. The whole cases were supported by writer check list. The students felt easy in doing the quiz.

In grade B, the percentage of students' achievement improved from cycle I to cycle II, it was happened because of some cases. The first is the writer motivated the students by giving a reward because basically, most of the students prefer like extrinsic motivation such as reward to instruct motivation. The students were motivated more enthusiastic in following the lesson in the class. The second is the researcher taught the teaching and learning material clearly. The writer explained the material with simple explanation so the students are easy to understand the task material. The third is the writer gave the best attention to the students had low capacity in English.

The analysis of observation sheet, diary notes and check list done by researcher and collaborate were found same conditions with the cases above. Collaborator worked together with writer analyzed that the writer had taught the material systematically and clearly so most of students weren't confused about the material given but they felt easy to comprehend the 
text. The students were brave to ask the question if they did not understand well. In writer' notes wrote during the teaching process, the students listen to writer's explanation seriously and they were more active because they were motivated to get a reward. In check list given to students, the cases were found that they were interested to study English if they were taught by using the Concept Attainment Model and they felt helpful in doing the quiz.

In grade $\mathrm{C}$, the percentage of the students' achievement improved from cycle I to cycle II. There are some reasons why the percentages of the students' achievement are improved from cycle I to cycle II. The first, the four of these students were lacked motivated to improve their score. They thought that English is so difficult so they did not have efforts to improve their score. The second, they had low capacity in comprehending the material. The teaching material had taught with simple explanation but they were still difficult to comprehend the text. It was happened because they had medium intelligent to understand the material quickly. The third, most of them were not self-confidence in doing the quiz, they did not self-confidence to their answering, so they cheated their friends' work.

The third cases above were found out in researcher' notes in diary notes. The writer' notes were written that there were some students cheated to their friends' work because they were not confidence to their self answering. Actually they were more active in the class but they did not have high intelligent so they difficult to understanding the material. The lecturer' giving check list to the students in the last meeting was found that they felt helpful in comprehending the text.

In grade $\mathrm{D}$ and $\mathrm{E}$, the percentage of the students' achievement decreased from cycle I to cycle II. It was happened because the researcher had used The Concept Attainment Model more systematic so most of the students comprehend the teaching material well. The writer made the condition more comfortable and enjoyable such as making a quiz, so the students felt relaxing and interesting in following the lesson process.

The collaborator worked together with writer in filling out observation sheet, the whole points had been better such as teach did the teaching learning process based on the lesson plan so the material taught systematic, most of the students were more active and enthusiast in following the lesson, the interaction between the teacher and students better than the last cycle, based on the writer' notes in diary notes, the students' condition same with observation.

The whole cases were supported by writer check list too, most of the students felt helpful in understanding the material given and to doing the quiz, the whole condition above made the percentage of the students' achievement decreased from cycle I to cycle II.

\subsection{The Research Finding}

Based on the analysis, it was found that Students' Reading Achievement through the Concept Attainment Model was able to improve the students' achievement in reading comprehension. The students' achievement improvement was significant as showed in Pre- 
test, cycle I and cycle II. The application of the Attainment Model helped the students to be easier in learning reading comprehension. Students were given the chance to share their idea with others friends.

\subsection{Discussion}

In this study, we could find that not all students got improvement for their score because they did not actively participate in learning process and also some students who did not get any improvement in cycle I and cycle II. This research had proved the effectiveness of applying The Concept Attainment Model; it was shown in table 1 the students' score from the pre-test, cycle I and cycle II. It was caused the teacher controlled the class better, directly admonished the students who were noisy. So the class become quitter and also provided more interesting activity in cycle II.

Students' data in cycle II showed that the mean of students' score were higher than the mean of the students' score in cycle I and also better than the pretest. In the last test of cycle II, there were 20 students who get the score above 70 score and only 4 students who got score under 70 score, and the highest score was 90 . This improvement not only happened in the mean of students' score but also the expression, interest and excitement of the students showed that here was improvement. As the result, Student Teams Achievement Divisions affected interesting and activating of the students in following the lesson and the students' score had been better in each cycle than before doing the research.

\section{REFERENCE}

Ahmet et al. 2012. A Comparative Study of Effectiveness of Concept Attainment Model and Traditional Method in Teaching of English in Teacher Education Course. Vol 12: 3 March 2012, ISSN 1930-2940. www. Langugeindia. Com.

Edgen, D. P., Donal P, Kauchak \& Robert J. H. 1979. Strategies for Teacher. United States of America.

Hornby, A. S. 1994. Oxford Advanced Learner's Dictionary. New York: Oxford University Press.

Grabe, william and Stoller, Fredricka L. 2002. Teaching and Researching Reading. England: Pearson Education.

Joyce, B \& Weil, M. 1980. Models of Teaching. Second Edition. United States of America.

Joyce, B \& Weil, M. 1995. Models of Teaching. United States of America.

Joyce, B \& Weil, M. Models of Teaching. United States of America. 
Martomidjojo, R. 2009. Model Pembelajaran Concept Attainment. http://russamsimartomidjojocentre.blogspot.com/2009/03/model-pembelajaranconcept-attainment.html. Accessed on Nopember 15, 2018.

Panjaitan, Evalina.2010. Improving Students' Vocabulary Achievement Through Anagram. Un publish. University Of Medan: Medan.

Rice, Melinda. 2009. Reading Comprehension Skills and Strategies. http://eps.schoolspecialty.com/downloads/research_papers/mc_research.pdf. accessed on Nopember 15, 2018.

Sapra, R. 2011. Concept Formation. Volume 2. Issue 4. http://karyailmiah.um.ac.id/index.php/KSDP/article/view/8054. accessed on Nopember 15, 2018.

Talkmitt, S. 2008. Teaching Strategies. Texas Tech University T- STEM Center/CISERCAST.http://olc.spsd.sk.ca/de/pd/instr/strats/cattain/index.html. Accessed on Nopember 20, 2018.

Utatri, Ayu.2011. Improving Students' Vocabulary Mastery Through Memory Strategy. Un publish. University Of Medan: Medan.

Wallace, M.J. 1998. Action Research for Language Teachers. Cambridge:

Cambridge University Press 